\title{
Effect of Heading Back on Photosynthesis, Yield and Fruit Quality in Pear
}

\author{
Shehbaz SINGH, Parmpal S GILL*, Wasakha S. DHILLON, Navprem SINGH \\ Punjab Agricultural University, Department of Fruit Science, Ludhiana, India; parmpalgill@pau.edu (*corresponding author)
}

\begin{abstract}
A field study was conducted to examine the effect of heading back of pear plants on photosynthesis, yield and fruit quality in pear trees cv. 'Patharnakh'. Plants were maintained at heights of $1.0 \mathrm{~m}, 1.5 \mathrm{~m}, 2.0 \mathrm{~m}, 2.5 \mathrm{~m}$ and $3.0 \mathrm{~m}$ from ground level by removing top of the canopy during dormant season, while the control trees were not given any pruning treatment. The photosynthesis rate (Pn) and photosynthetic active radiation (PAR) were taken from April to July at fortnightly interval. Highest Pn of leaves trees was observed at morning time and it showed a positive relationship with PAR received. Both increased with advancement in season and recorded maximum in the $2^{\text {nd }}$ fortnight of June, thereafter declined slightly. PAR and Pn increased with intensity of the pruning. Upper canopy of all the treatments recorded highest photosynthesis rate. Fruit yield per tree increased as the pruning height was raised and was recorded maximum in $2.5 \mathrm{~m}$ level of pruning. Fruit size enlarged linearly with the intensity of pruning. Pruning treatment improved soluble solids content of fruit.
\end{abstract}

Keywords: PAR, pear, photosynthesis, pruning

\section{Introduction}

Among different pear varieties, Patharnakh pear (Pyrus pyrifolia) is extensively grown, due to its wider adaptability to sub-tropical conditions of north-westren India. Traditionally, trees of this cultivar have been trained to modified leader system and planted at tree density of 180 plants per hectare. It is vigorously growing cultivar and prolific bearer. When maintained under modified leader system tree attain large size that leads to shading within tree canopy and the bearing shifts to outer parts while the interior of tree becomes less productive resulting in poor quality fruits and decreased yield per unit area. The fruits on upper canopy of tree are difficult to harvest and vulnerable to bird and high velocity wind damage. In addition, pest management is more difficult in higher trees due to poor spray coverage at the tops of the trees. Therefore, pear production is more difficult in tall trees and is likely to be less efficient than production on shorter trees (Grossman et al., 1997). Canopy management techniques involve maximum utilization of light as it is most important component of fruit production. Light is known to influence flower bud differentiation, fruit set and fruit quality (Jackson, 1980). The shaded canopy with high interception lowers fruit production and quality (Wagenmakers, 1989). The natural tendency of pear tree is to grow upright with strong central leader and suppressing lateral buds (Das, 2010). Several practices including growth regulators (paclobutrazol, CCC, MH, promaline, XE 1019, AMO1618), dwarfing rootstocks (Quince - C, Oregon 211, OH x F-230) and pruning have been used to manage the size of the tree (Srivastava et al., 2010). However, the concentration of growth regulators must be high to check the growth and the control is temporary, and these leave unacceptable residues (Lombard, 1982). Under subtropical conditions where summers are long and hot, no dwarfing rootstock has been recognized for pears and hence, managing the canopy through pruning remains the ultimate choice. So the pruning approach should be aimed to regulate the tree size without loss of yield per unit area. The principle underlying modern orchard planting system is to enhance light distribution within tree canopy through optimized total light interception by reducing individual tree size form and arrangement (Tustin et al., 1998). In fruit crops, the most commonly used approach for improving light interception include planting design, pruning and training of the trees (Jackson, 1980). Pear is the species that, throughout its orchard life, best lends itself to mechanical hedging or toping, can be done after harvest or in winter (Sansavini and Musacchi, 1994). Pruning helps in immediate reduction in tree size as the consequence of tissue removal. Removing the apical portion allows the lower dormant lateral buds to develop. The study was conducted with the objective to determine effect of pruning on photosynthesis within the plant canopy, yield and quality of Patharnakh pear.

\section{Materials and methods}

The experiment was conducted at experimental orchard of Department of Fruit Science, Punjab Agricultural University, Ludhiana (India). The Patharnakh pear plants spaced at high density ( $4 \times 4 \mathrm{~m})$ on Pyrus pashia rootstock, were planted in 1998. After seven years, the plants were headed back to different heights i.e $1.0 \mathrm{~m}\left(\mathrm{~T}_{1}\right), 1.5 \mathrm{~m}\left(\mathrm{~T}_{2}\right)$, $2.0 \mathrm{~m}\left(\mathrm{~T}_{3}\right), 2.5 \mathrm{~m}\left(\mathrm{~T}_{4}\right)$ and $3.0 \mathrm{~m}\left(\mathrm{~T}_{5}\right)$ from the ground 
level during dormant season. The control trees $\left(\mathrm{T}_{6}\right)$ were not given any heading back treatment and were allowed to grow to their natural habit. Experiment was laid out in randomized block design with five replications per treatment. Heading back resulted in sprouting of new shoots which were thinned out annually during the winter season when plants are in dormant phase. To avoid any microbial infection, the cuts were applied with bordeaux paste after pruning. The orchard is under the management practices according to the local standard program for pears; surface flooding irrigation was applied. Photosynthesis observations i.e. photosynthesis rate and photosynthetic active radiation were taken on clear sky days at three time intervals i.e. morning (8.00-10.00 am), afternoon (12.00-2.00 $\mathrm{pm}$ ) and evening (4.00-6.00 pm) continuously from April to July at fortnightly intervals by using a hand held photosynthesis system (Model CI 340, CID Inc. USA) on fully expanded leaves. For taking observation, the canopy of tree was divided into three parts i.e upper, middle and lower. The four to five leaves were marked in each of the respective portion. The plant height of tree was supposed to increase one foot in every month. So the photosynthetic parameters in the upper canopy of the experimental trees were recorded by taking leaves approximately one foot above from the previously marked leaves after every month. However, the photosynthetic parameters of lower and middle canopy were recorded from the marked leaves at every fortnight. The fruit yield was calculated at the time of harvesting. Fruit size in terms of length $\times$ breadth was measured with the help of digital Vernier Caliper (Mitutoyo, Japan). Twenty fruits, per sample from each replication were taken to record the physico-chemical parameters. The soluble solids content of the juice was recorded with the help of hand refractrometer (Erma, Japan) and the values were expressed as degree Brix after subjecting to correction chart at $20^{\circ} \mathrm{C}$ temperature. Total titratable acid content was determined by titrating fruit juice against $\mathrm{N} / 10$ sodium hydroxide using phenophthalein as an indicator. The data obtained from the experiments were subjected to analysis of variance (ANOVA) using statistical analysis software package CPCS1 (Cheema and Singh, 1990).

\section{Results and discussion}

The photosynthesis $(\mathrm{Pn})$ as well as PAR were significantly affected by various pruning treatments within canopy of Patharnakh pear trees (Fig. 1 A-C). It appeared that the photosynthesis rate was positively correlated with amount of photosynthetic active radiations recorded at respective canopy level. Photosynthesis of the leaves depends directly on light exposure (Flore and Lakso, 1989). The photosynthesis rate varied from 3.1 to $19.2\left(\mu\right.$ mole m$^{-2} \mathrm{sec}^{-}$ ${ }^{1}$ ) depending upon the season and portion of canopy from which it was taken. Overall, the highest PAR was received in afternoon followed morning and least was recorded in
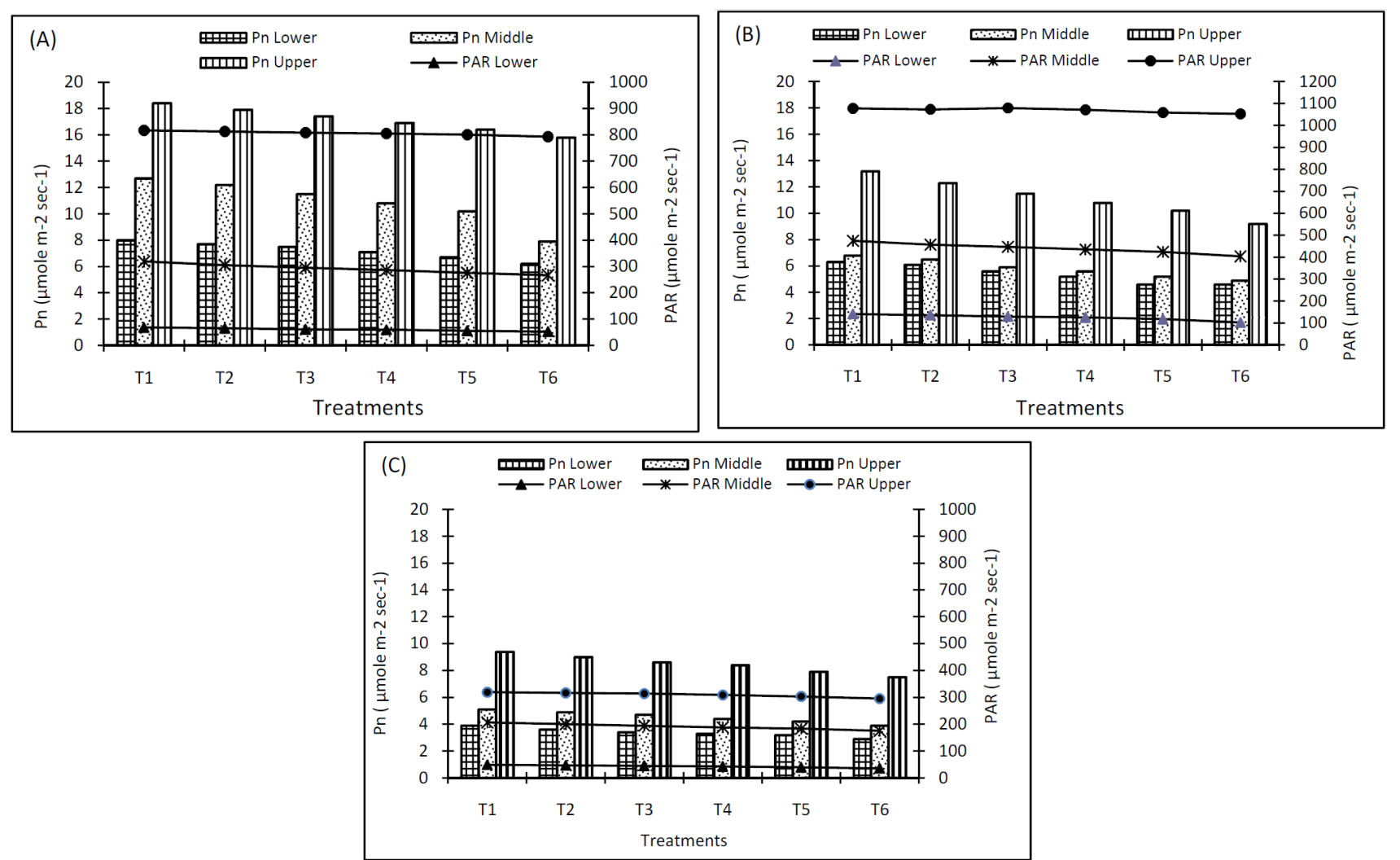

Fig. 1. Effect of pruning treatments on PAR and Pn during morning (A), afternoon (B) and evening (C) at different level of Patharnakh pear tree canopy 
92

the evening throughout the canopy during the entire period of study. However, the photosynthesis rate was highest in the morning and lowest in the evening. Under the sub-tropical conditions of north-western India, the temperature during summer months rises sharply during the afternoon, which might force the leaves for partial closing of stomata resulting in decreased photosynthesis rate, although the PAR were maximum at this time. At evening, the minimum lower PAR and photosynthesis might be due to lower light availability as the height of pruned trees increased from east to west direction which caused shading effect to trees under the respective treatment. Rate of photosynthesis increased with reduction in tree height kept at the time of pruning. The maximum mean photosynthesis rate was observed in trees pruned at $1.0 \mathrm{~m}$ height.

The higher Pn in heavily pruned trees can be attributed to higher availability of photosynthetic active radiations under these treatments. Singh and Singh (2007) also reported an increase in photosynthesis and PAR with increase in pruning levels in guava. Enhanced photosynthetic activity is related to light interception (Chadha and Awasthi, 2005). The greater light interception under upruned tree tall trees resulted lowest photosynthesis rate of leaves in all three parts of tree canopy. These results support of other study that a dense canopy can cause internal shading, thus decreasing photosynthetic activity of plant (Flore and Lakso, 1989). Similarly, the upper canopy of the plant recorded higher photosynthesis rate which decreased with canopy depth and the minimum was recorded in lower canopy. Earlier studies in apples also indicate that per cent photosynthetic flux transmission declined from top to the bottom of canopy irrespective of training system (Ferree, 1989).

The seasonal variations had considerable effect on photosynthetic active radiation as well as rate photosynthesis (Fig. 2 A-C). These parameters continued to increase with advancement in season from April to June and declined subsequently. The maximum Pn and PAR values were recorded in second fortnight of June and minimum during the beginning of the season in April. These results indicate that with advancement in season the PAR increased that resulted in higher photosynthetic efficiency of the leaves. The lower photosynthesis rate at the end of the season may be due to reduction of photosynthetic active radiations.

The data presented in Tab. 1 reveal that there exists a significant difference in fruit yield with respect to the different pruning treatments. The higher trees were expected to have a higher yield potential, at least to a maximum yield limit. The yield is increased up to the pruning height $2.5 \mathrm{~m}$ level and subsequently a non-significant decline was noticed. A higher number of fruits per tree should be excepted for the highest trees (Winter, 1978). Significantly maximum fruit yield of $55.5 \mathrm{~kg} /$ tree was recorded in the $2.5 \mathrm{~m}$ level of pruning treatment. Minimum fruit yield was recorded in trees pruned at $1.0 \mathrm{~m}(13.9 \mathrm{~kg} /$ tree $)$ height followed by $1.5 \mathrm{~m}(30.4 \mathrm{~kg} /$ tree $)$ and $2.0(46.8 \mathrm{~kg} /$ tree $)$ pruning level. In spite of largest tree size, the control fails to produce highest yields which could be attributed to shaded canopy (Wagenmakers, 1989). Lower fruit yield in severely pruned trees was due to lesser crop load and low-
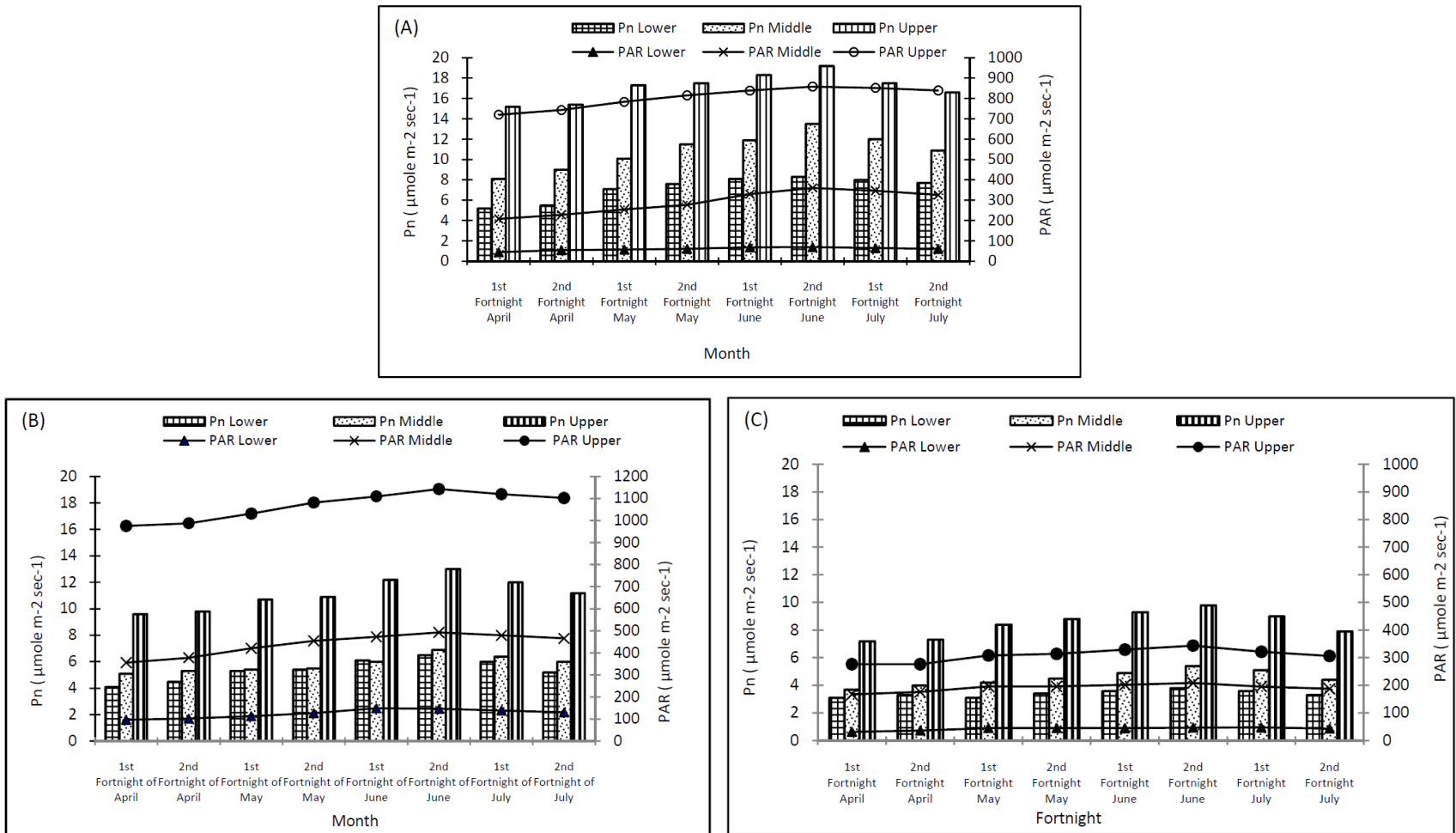

Fig. 2. Effect of seasonal variations on $P A R$ and Pn during morning (A), afternoon (B) and evening (C) at different level of Patharnakh pear tree canopy 
Tab. 1. Effect of heading back on the yield, fruit size and quality of Patharnakh pear

\begin{tabular}{cccccc}
\hline Treatment & $\begin{array}{c}\text { Fruit yield } \\
(\mathrm{kg} / \text { tree })\end{array}$ & $\begin{array}{c}\text { Fruit length } \\
(\mathrm{cm})\end{array}$ & $\begin{array}{c}\text { Fruit breadth } \\
(\mathrm{cm})\end{array}$ & $\begin{array}{c}\text { TSS } \\
(\%)\end{array}$ & $\begin{array}{c}\text { Acidity } \\
(\%)\end{array}$ \\
\hline $\mathrm{T}_{1}$ & $13.9^{\mathrm{d}}$ & $7.72^{\mathrm{a}}$ & $7.59^{\mathrm{a}}$ & $12.43^{\mathrm{ab}}$ & $0.31^{\mathrm{a}}$ \\
$\mathrm{T}_{2}$ & $30.4^{\mathrm{c}}$ & $7.53^{\mathrm{b}}$ & $7.38^{\mathrm{ab}}$ & $12.56^{\mathrm{a}}$ & $0.30^{\mathrm{a}}$ \\
$\mathrm{T}_{3}$ & $46.8^{\mathrm{b}}$ & $7.06^{\mathrm{c}}$ & $7.06^{\mathrm{c}}$ & $12.30^{\mathrm{bc}}$ & $0.28^{\mathrm{a}}$ \\
$\mathrm{T}_{4}$ & $55.5^{\mathrm{a}}$ & $7.03^{\mathrm{c}}$ & $6.83^{\mathrm{c}}$ & $12.30^{\mathrm{bc}}$ & $0.28^{\mathrm{a}}$ \\
$\mathrm{T}_{5}$ & $53.4^{\mathrm{a}}$ & $6.65^{\mathrm{d}}$ & $6.34^{\mathrm{d}}$ & $12.08^{\mathrm{cd}}$ & $0.28^{\mathrm{a}}$ \\
$\mathrm{T}_{6}$ & $54.7^{\mathrm{a}}$ & $6.00^{\mathrm{c}}$ & $5.98^{\mathrm{c}}$ & $11.85^{\mathrm{d}}$ & $0.32^{\mathrm{a}}$ \\
\hline
\end{tabular}

${ }^{*}$ Significance level at $p<0.05$

est canopy volume in the $1.0 \mathrm{~m}$ and $1.5 \mathrm{~m}$ levels of pruning. In apples, the crop load was reduced with increasing pruning severity (Bound and Summers, 2001) and the tree height of $275-325 \mathrm{~cm}$ was optimal for the higher yield of first class fruit (Callesen, 1993).

Fruit size is a major criterion of pear fruit quality. It depends upon the both canopy carbohydrate supply and total demand for fruit growth ( $\mathrm{Li}$ et al., 2003). Fruit size in terms of length and breadth has been presented in the Tab. 1. Across the various pruning treatments there exist a clear negative relationship between fruit size and pruning height. Maximum fruit size was recorded from trees retained at minimum height. The trees received heavy pruning produced significantly lower fruit yield than the unpruned control trees and the larger fruit size in heavily pruned trees may be attributed to lower fruiting density and increased leaf: fruit ratio that supplied higher photosynthates to the fruits under these treatments. Control trees that produce maximum number of fruits consequently produced fruits with lowest size. Smaller fruit size may be due to higher competition for photoassimilates among the developing fruit. Earlier studies shown that pruning is matched by an increase in fruit size in pear (Westwood $e t$ al., 1964), apples (Bound and Summer, 2001; Rom, 1992) and peaches (Singh and Chauhan, 1998).

In present study, soluble solids content of fruits were significantly altered by various pruning treatment (Tab. 1). The trend indicated that soluble solids content in fruits improved with reduction in pruning height. The control tree recorded minimum soluble solids content while the maximum soluble solids were recorded in fruits harvested from trees under $2.5 \mathrm{~m}$ pruning treatment. Minimum soluble solids content were registered in control treatment which was at par $3.0 \mathrm{~m}\left(\mathrm{~T}_{5}\right)$ pruning treatment. Higher soluble solids content in pruned trees are credited to enhanced carbohydrate supply (Sansavini and Musachhi, 1994). In apples, fruits borne on shaded lower parts had lesser soluble solid contents (Callesen, 1993). No significant differences were found in acid content of fruits with respect to various pruning treatments, though fruits from unpruned trees recorded highest acid content. Higher soluble solids and lower acid content in fruits from low headed trees indicate earliness in maturity as compared to control trees.

\section{Conclusions}

The present study showed that that low headed training in pear improved photosynthetic active radiation and photosynthetic efficiency of trees with good fruit quality. However, severe heading back significantly reduced the fruit yield of tree. The unpruned trees recorded poor fruit quality.

\section{References}

Bound SA, Summers CR (2001). The effect of pruning level on fruit quality on red 'Fuji' apple. Prog 7th Int Symp on Orchard and Plant System 557:295-301.

Callesen O (1993). Influence of apple tree height on yield and fruit quality. Acta Hort 349:111-115.

Chadha KL, Awasthi RP (2005). The Apple: improvement, Production and Post Harvest Management. Malhotra Publishing House, New Delhi, 182-201 p.

Cheema HS, Singh B (1990). A user's manual to CPCS1. Punjab Agricultural University, Ludhiana $40 \mathrm{p}$.

Das B (2010). Training and Pruning, 277-304 p. In: Sharma RM, Pandey SN, Pandey V (Eds.). The Pears: Production, Post-Harvest Management and Production. IBDC Publishers, Lucknow, U.P (India).

Ferree DC (1989). Influence of orchard management systems on spur quality, light and fruit within the canopy of 'Golden Delicious' apple trees. J Amer Soc Hort Sci 114:869-875.

Flore JA, Lakso AN (1989). Environmental and physiological regulation of photosynthesis in fruit crops. Hort Rev 11:11157.

Grossman YL, Elkins RB, Dejong TM (1997). Summer pruning does not appear to increase Bartlett pear crop yield on reduced height trees in northern California. Acta Hort 451:543-550.

Jackson JE (1980). Light interception and utilization by orchard systems, 208-67 p. In: Janick J (Ed.). Hort Rev Vol. 2. The AVI Publishing Company Inc., Westport, Connecticut.

Li KT, Lakso AN, Piccioni R, Robinson T (2003). Summer pruning effects on fruit size, fruit quality, return bloom and fine root survival in apple trees. J Hort Sci and Biotechnol 78:755-761.

Lombard PB (1982). Special considerations in orchard design, 
94 training and pruning systems for pear trees. Acta Hort 124:171-175.

Rom C (1992). Spur pruning 'delicious' apple for improved spur quality and yield. Acta Hort 322:55-68.

Sansavini S, Musacchi S (1994). Canopy architecture, training and pruning in the modern european pear orchards: an overview. Acta Hort 367:152-172.

Singh D, Chauhan JS (1998). Effect of different pruning and nitrogen levels on growth, yield and quality of peach (Prunus persica Batsch). Haryana J Hort Sci 27:92-97.

Singh VK, Singh G (2007). Photosynthetic efficiency, canopy micro climate and yield of rejuvenated guava trees. Acta Hort 735:249-257.

Srivastava KK, Singh RR, Sundouri AS (2010). Canopy management in temperate fruits, 137-142 p. In: Banday FA, Sharma MK (Eds.). Advances in Temperate Fruit Production, Kalayani Publishers, New Delhi.
Tustin S, Cashmore WM, Bensley RB (1998). The influence of orchard row canopy discontinuity on irradiance and leaf area distribution in apple trees. J Hort Sci and Biotechnol 73:289-297.

Wagenmakers PS (1989). Productivity, growth and light interception in the ISHS planting trial in the Netherlands. Acta Hort 243:249-252.

Westwood MN, Degman ES, Grim JH (1964). Effects of longterm fertilizer management practices in growth and yield of pears grown in clay adobe soil. Oregon Agr Exp Stat Tech Bull 82:35.

Winter F (1978). Reasons for adoption of different systems in different countries. Acta Hort 65:279-283. 